\title{
Antioxidant Potential and Antitumour Activities of Nendran Banana Peels in Breast Cancer Cell Line
}

\author{
P. S. KUMAR*, S. DURGADEVI, A. SARAVANAN AND S. UMA \\ ICAR-National Research Centre for Banana, Trichy-620 102, ${ }^{1}$ Dr. N. G. P. Arts and Science College, Coimbatore-620 148, \\ India
}

Kumar et al.: Anticancer activity of Banana peel

The present study was aimed to evaluate the antioxidant and antitumor activities of the aqueous methanol extract of Nendran banana peel as a valuable source for bioactive compounds against cancer. Free radical scavenging activity of the peel extracts was evaluated using 1,1-diphenyl-2-picrylhydrazyl and ferric reducing antioxidant power assay. The antitumor activity on MCF-7 breast cancer cell line was determined by the 3-(4,5-dimethylthiazol-2-yl)-2,5-diphenyltetrazolium bromide and ethidium bromide/acridine orange staining assay. Extract of banana peel was more efficient in reducing ferric ion with the increase in concentration and exhibited $\mathrm{IC}_{50} \mathbf{1 8 0 . 3 3} \mu \mathrm{g} / \mathrm{ml}$, free radical inhibition activity under 2,2-diphenyl-1picrylhydrazyl hydrate assay. Flavonoid content was high $(51.47 \mu \mathrm{g} / \mathrm{ml})$ in the peel extract, which could have contributed to the antioxidant activity. The antioxidant enzyme concentration such as ascorbate peroxidase, catalase, peroxidase and superoxide dismutase were found higher in the fruit pulp than peel. As the concentration of extract increased from 20 to $200 \mu \mathrm{g} / \mathrm{ml}$, the cell viability of MCF-7 decreased from 91.14 to $24.7 \%$. The $\mathrm{IC}_{50}$ values of plant extract-treated cells $(120.6 \mu \mathrm{g} / \mathrm{ml})$ showed typical apoptotic and necrotic morphological features such as condensed nuclei, membrane blebbing and formation of apoptotic bodies. This indicated the efficiency of sample against breast cancer with the highest inhibition of growth.

Key words: Nendran banana peel, bioactive compounds, apoptotic index, phenols, flavonoids, antioxidant

Cancer is a hyper-proliferative disorder, which involves transformation, deregulation of apoptosis, proliferation, invasion, angiogenesis, and metastasis. Worldwide, more than half a million people died of cancer every year, at a rate of 1500 patients every day $^{[1]}$. Breast cancer is the second leading cancer in women, accounting for $25 \%$ of all cases ${ }^{[2]}$. Currently tamoxifen, selective oestrogen receptor modulator, is widely used in the prevention and treatment of oestrogen receptor positive breast cancer ${ }^{[3]}$. However, a significant number of patients develop tamoxifen resistance and experience severe side effects ${ }^{[4,5]}$. It is therefore, imperative to search for newer compounds, which are effective, greener and not with many side effects.

As the conventional cancer therapies failed to fulfil the criteria for successful cancer treatments, recent research revolved around the urgency to develop suitable therapy for the cure of cancer with no toxic effects through methodical and scientific exploration of the enormous pool of synthetic, biological, and natural products ${ }^{[2,6-9]}$. Plant-derived natural products

*Address for correspondence E-mail: psureshars@gmail.com

May-June 2019 received significant attention due to their diverse pharmacological properties and cancer preventive effects. With the presence of flavonoids, alkaloids and terpenes, these offer different forms of cytotoxic effects such as cell proliferation inhibition, apoptosis induction or modulating signal transduction, without exhibiting considerable damage to normal cells ${ }^{[7-13]}$. These are relatively new, but very promising strategies in preventing cancer due to both additive and synergistic effects ${ }^{[8]}$. Interest in the pharmacological effects of bioactive compounds on cancer treatments and prevention has increased dramatically over the past $20 \mathrm{y}$. Many fruits such as guava ${ }^{[13]}$, banana ${ }^{[11]}$, papaya ${ }^{[12]}$, lemon $^{[14]}$, orange ${ }^{[15]}$, apple, water melon, litchi are reported to possess proven medicinal activities when

This is an open access article distributed under the terms of the Creative Commons Attribution-NonCommercial-ShareAlike 3.0 License, which allows others to remix, tweak, and build upon the work non-commercially, as long as the author is credited and the new creations are licensed under the identical terms

Accepted 30 March 2019

Revised 05 Deceember 2018

Received 29 September 2018

Indian J Pharm Sci 2019;81(3):464-473 
used as a whole fruit, seeds, leaves, and as peels with anticancer potential ${ }^{[16-18]}$.

Banana is one of the major fruit crops grown in India with the production of more than 30 million tons per annum. The Nendran banana is a dual-purpose banana, being utilized as a fruit and as in cooked form. Moreover, the chips, oil-fried products of Nendran increase the bioavailability of lipid soluble $\beta$-carotene in human diet, was reported by National Institute of Nutrition, India ${ }^{[10]}$. The chips industry with the production of 2 lakh tons of chips and the value of 500 crores annually, generate equal volume of peel and the amount of waste is expected to increase with the development of clustered processing industries ${ }^{[11]}$. Peel, the main by-product of banana constitutes 30-40\% of the fresh biomass of the Nendran fruit was found to contain much higher beneficial compounds compared to other fruit parts ${ }^{[12,13]}$. They are rich source of crude protein (6-9 \%), crude fat (3.8-11\%), total dietary fibre (43.2$49.7 \%$ ), polyunsaturated fatty acids, essential amino acids and micronutrients on dry weight basis. Banana peels are also a good source of lignin (6-12\%), pectin (10-21\%), cellulose (7.6-9.6\%), hemicelluloses (6.4$9.4 \%)$ and galacturonic acid ${ }^{[9]}$. The natural bioactive compounds such as carotenoids, quercetin derivatives, phenolic acids and saponins are found in the peels in high concentration ${ }^{[14]}$. Like pulp, banana peel flour offers scope for making new processed nutraceutical products. These parts of banana have long been used in traditional medicine in Asia and Africa ${ }^{[17]}$. Peel is used to make poultice for wounds to reduce pain and swelling. Peel, placed on a wart, with the yellow side out, could be an alternative to kill of wart and to reduce the irritation after a mosquito bite ${ }^{[18,19]}$. Therefore, bioactive compounds from various parts of banana are considered to be natural free radical defence that were acknowledged to be beneficial for human health as an antioxidant, antitumor, and antimicrobial agent ${ }^{[18,19]}$.

Considering the need for effective anticancer agents, and the association of fruit and vegetable consumption with reduced cancer risk $^{[11,9,20-24]}$, present study was conducted to profile the bioactive compounds in Nendran peel extract and to assess its antioxidant and anticancer activities with the focus to determine their ability to inhibit the proliferation of human breast cell line (MCF-7).

\section{MATERIALS AND METHODS}

The peel of the banana cv. Nendran was collected from the bakeries, making banana chips and from the experimental farm of ICAR-National Research Centre for Banana, Trichy, Tamil Nadu. The basic parameters such as fruit weight $(\mathrm{g})$, length $(\mathrm{cm})$, fruit diameter $(\mathrm{cm})$, peel weight $(\mathrm{g})$, pulp weight $(\mathrm{g})$, firmness $(\mathrm{kgf})$ and colour index were recorded. The peel and pulp were freeze-dried and ground into a fine powder using a mortar and pestle and passed using US 100 sieve (particle size $0.15 \mathrm{~mm}$ ) and stored at $4^{\circ}$ in a sealed poly propylene bag until further analysis.

\section{Quantitative analysis of secondary metabolites:}

Total carotenoids ${ }^{[7]}, \beta$-carotene ${ }^{[8]}$, total $\operatorname{starch}^{[11]}$, total and reducing sugar, protein ${ }^{[9]}$, superoxide dismutase $(\mathrm{SOD})^{[8]}$, catalase (CAT), peroxidase (POX), glutathione reductase ${ }^{[12]}$, ascorbate peroxidase (APOX) and mineral nutrient ${ }^{[8]}$ were estimated using standard procedures. Fresh samples of peel and pulp were used for the estimation of phenols, flavonoids, secondary metabolites, minerals and other proximate analyses.

\section{Estimation of total phenolic compounds:}

Phenolic compounds from fruit peel and pulp extract were estimated according to the method outlined by Kumar et al. ${ }^{[8]}$. In brief, $1 \mathrm{~g}$ of fresh sample was extracted using $80 \%$ aqueous methanol and $1 \mathrm{ml}$ of the sample was mixed with $1 \mathrm{ml}$ of Folin-Ciocalteau phenol reagent and $1 \mathrm{ml}$ of $20 \%$ anhydrous sodium carbonate. The optical density was measured after $30 \mathrm{~min}$ at a wavelength of $650 \mathrm{~nm}$. The phenolic content was obtained from a standard curve of gallic acid and then calculated as milligram phenolic per gram fresh weight of sample.

\section{Estimation of total flavonoids:}

Aluminium chloride colorimetric technique was used for flavonoid estimation ${ }^{[10]}$. Fruit peel and pulp was extracted using $1 \mathrm{~g} / 10 \mathrm{ml}$ of $80 \%$ aqueous methanol solvent. From the extract $0.5 \mathrm{ml}$ was mixed with $1.5 \mathrm{ml}$ of methanol, $0.1 \mathrm{ml}$ of $10 \%$ aluminium chloride, $0.1 \mathrm{ml}$ of $1 \mathrm{M}$ potassium acetate and $2.8 \mathrm{ml}$ of distilled water, left at room temperature for $30 \mathrm{~min}$ and then the absorbance of the reaction mixture was measured at $416 \mathrm{~nm}$ with a double beam UV/Vis spectrophotometer (UV-3200, LabIndia). The total flavonoid content was obtained from a calibration curve, using quercetin as standard and then calculated as milligram flavonoids/g fresh weight of sample.

\section{Diphenyl picrylhydrazyl (DPPH) radical scavenging assay:}

DPPH stable free radical scavenging activity was 
determined according to the protocol of Kumar et al. ${ }^{[8]}$ with a slight modification. Five grams of fresh sample was taken and extracted with $25 \mathrm{ml}$ methanol. One millilitre of the extract was mixed with an equal volume of methanol to which $1 \mathrm{ml}$ of $200 \mu \mathrm{M} \mathrm{DPPH}$ was added. Control, blank and sample solutions were incubated in the dark at $37^{\circ}$ for $30 \mathrm{~min}$. Absorbance was measured at the end at $515 \mathrm{~nm}$ against control using a spectrophotometer. BHA was used as the reference material and the percent inhibition was calculated by comparing the optical density values of the extract with those of the controls.

\section{Ferric reducing antioxidant power (FRAP):}

The antioxidant capacity of pulp and peel of the fruits were estimated spectrophotometrically following the procedure reported by Benzie and Strain ${ }^{[25]}$. FRAP reagent was prepared by mixing $300 \mathrm{mM}$ acetate buffer, $10 \mathrm{ml}$ 2,4,6-tripyridyl-s-triazine in $40 \mathrm{mM} \mathrm{HCl}$ and $20 \mathrm{mM} \mathrm{FeCl} 3 \cdot 6 \mathrm{H}_{2} \mathrm{O}$ in the proportion of $10: 1: 1$ at $37^{\circ}$. $3.995 \mathrm{ml}$ of freshly prepared working FRAP reagent was pipetted and mixed with $5 \mu 1$ of the appropriately diluted plant sample and mixed thoroughly. An intense blue colour complex was formed and the absorbance at $593 \mathrm{~nm}$ was recorded against a reagent blank after 30 min incubation at $37^{\circ}$. The standard graph was plotted using $\mathrm{FeSO}_{4} \cdot 7 \mathrm{H}_{2} \mathrm{O}$ at different concentrations. The reduction of $\mathrm{Fe}^{3+}$ into $\mathrm{Fe}^{2+}$ was observed by comparing the absorbance and the FRAP activity was expressed as $\mu \mathrm{M} \mathrm{FeSO}_{4} / \mathrm{ml}$. $\beta$-hydroxy anisole (BHA) was used as standard.

\section{MTT assay for cell cytotoxicity:}

Lyophilized peel powder (10 g) was extracted using $80 \%$ methanol (1:3) and was concentrated to obtain $18 \%$ aqueous methanol extract. The extract was used for further analysis of anticancer activity using MTT and acridine orange/ethidium bromide (AO/EB) assay. Human breast carcinoma (MCF-7) cell line was obtained from the National Centre for Cell Science, Mumbai, were cultured in liquid medium (Dulbecco's modified Eagle media, DMEM) supplemented with $10 \%$ fetal bovine serum (FBS), $100 \mathrm{U} / \mathrm{ml}$ penicillin and $100 \mu \mathrm{g} / \mathrm{ml}$ streptomycin and maintained under $5 \% \mathrm{CO}_{2}$ atmosphere at $37^{\circ}$. Briefly, the cultured MCF-7 cells were harvested by trypsinization and pooled in a $15 \mathrm{ml}$ tube ${ }^{[12,26]}$. Then, the cells were plated at a density of $1 \times 10^{5}$ cells/well $(200 \mu 1)$ into $96-$ well tissue culture plate in DMEM medium containing $10 \%$ FBS and $1 \%$ antibiotic solution for $24-48 \mathrm{~h}$ at $37^{\circ}$. The wells were washed with sterile PBS and treated with various concentrations of $80 \%$ aqueous methanol extract in a serum free DMEM medium. Then, the cells were incubated at $37^{\circ}$ in a humidified $5 \% \mathrm{CO}_{2}$ incubator for 24 h. After the incubation period, MTT $(20 \mu \mathrm{l}$ of $5 \mathrm{mg} / \mathrm{ml})$ was added into each well and the cells incubated for another 2-4 h until purple precipitate was clearly visible under an inverted microscope. Finally, the medium together with MTT $(220 \mu 1)$ were aspirated off the wells and washed with 1X PBS $(200 \mu 1)$. Furthermore, to dissolve formazan crystals, DMSO $(100 \mu \mathrm{l})$ was added and the plate was shaken for $5 \mathrm{~min}$. The absorbance for each well was measured at $570 \mathrm{~nm}$ in a microplate reader (Thermo Fisher Scientific, USA), the percent cell viability and $\mathrm{IC}_{50}$ values were calculated using GraphPad Prism 6.0 software (USA).

\section{AO/EB staining:}

$\mathrm{AO} / \mathrm{EB}$ staining assay was performed as outlined by Ciniglia et al. ${ }^{[24]}$. Briefly, $5 \times 10^{5} \mathrm{MCF}-7$ cells $/ \mathrm{ml}$ were seeded into the 24 well tissue culture plate and treated with the best optimized extract in a serum-free DMEM medium. The plate was incubated at $37^{\circ}$ in a $5 \% \mathrm{CO}_{2}$ incubator for $24 \mathrm{~h}$. After incubation, $50 \mu 1$ of $1 \mathrm{mg} / \mathrm{ml}$ $\mathrm{AO}$ and EB were added to the wells and mixed gently. Finally, the plate was centrifuged at $800 \mathrm{rpm}$ for $2 \mathrm{~min}$ and evaluated immediately within $1 \mathrm{~h}$ and examined at least 100 cells by fluorescence microscope using a fluorescent filter. Early apoptosis, late apoptosis and necrosis indices were calculated using the difference in 100 cells with the staining ${ }^{[24]}$.

\section{Statistical analyses:}

Results were calculated as mean \pm standard deviation (SD) for each group and were analysed using GraphPad Prism (V.7, GraphPad Software, CA, USA) statistical software. For calculation of significant difference between multiple groups, $t$ test was performed using SPSS (V.20.1, USA), one-way analysis of variance and post hoc analysis was performed with Tukey's test and $\mathrm{p}<0.05$ was considered statistically significant.

\section{RESULTS AND DISCUSSION}

The general physical parameters of the Nendran banana are presented in Table 1. Nendran a dual-purpose banana variety weighed between 140-225 g with the fruit length of 19.0-25.0 cm and the fruit circumference of 13 to $16.0 \mathrm{~cm}$. The pulp weight varied between 97.5 $124.67 \mathrm{~g}$ whereas the peel weighed in the range of 42.7-70.83 g. Colour, an important parameter for the selection of fruits expressed the L value of 43.6-52.4. 
TABLE 1: PHYSICAL PARAMETERS OF NENDRAN BANANA (AAB)

\begin{tabular}{lc}
\hline Parameters & Values \\
\hline Fruit weight $(\mathrm{g})$ & $140.8-225.34$ \\
Fruit length $(\mathrm{cm})$ & $18.5-24.3$ \\
Fruit circumference $(\mathrm{cm})$ & $12.5-15.4$ \\
Pulp weight $(\mathrm{g})$ & $97.5-124.67$ \\
Peel weight $(\mathrm{g})$ & $42.7-70.83$ \\
Firmness $(\mathrm{kgf})$ & $26.7-29.15$ \\
& $\mathrm{~L}=43.6-52.4$ \\
Colour index & $\mathrm{a}=16.21$ \\
& $\mathrm{~b}=21.9$ \\
Pulp to peel ratio & $1.75-2.28$ \\
\hline
\end{tabular}

This has shown that the fruit is light in colour with the medium redness value. The peel to pulp ratio was 1.7-2.28, this explained the need for the study as huge biomass is generated as a waste while utilizing banana fruits in processing industry.

Chemical parameters of both peel and pulp were analysed and presented in Table 2. All the basic nutrient parameters like sugar, carbohydrate, protein and fat were more in the pulp than in the peel. The pulp contained higher value on total suspended solids (TSS) than the peel. Higher TSS was required for palatability of the fruit pulp and for higher consumer acceptance, while making processed products. Similarly, reducing sugars, non-reducing sugars and total carbohydrates were more in the pulp than in the peel. However, the peel gave higher value for fat and the ash content. The higher fat content in the peel facilitates its use for the extraction of essential oil. The higher ash content indicated higher mineral accumulation in the peel than in the pulp (Table 3). The nutrient composition of the cultivar is mostly depended upon its genetic makeup with a little influence of the environment and added nutrients ${ }^{[11]}$. Accumulation of minerals is normally more in the peel than the pulp during fruit development stage. Among the minerals, potassium content was more with the values of 618.4 and $397.9 \mathrm{mg} / 100 \mathrm{~g}$ in the peel and the pulp, respectively followed by magnesium (536 and $421 \mathrm{ppm}$ ) and calcium (220 and $130 \mathrm{ppm}$ ). The positive effect of potassium on salt regulation and use of magnesium on reducing hypertension was welldocumented ${ }^{[3,17,21]}$. Consequently, these peels rich in minerals has a greater scope to be used in nutraceutical and cosmetic industries ${ }^{[11,22,23]}$ and as a supplement in bakery and biscuits units with its higher content of dietary fibre.

In the current investigation, aqueous methanol extract of Nendran peel showed highest flavonoid content of $51.47 \mu \mathrm{g} / \mathrm{g}$ and phenolic content of $0.54 \mathrm{mg} / \mathrm{g}$, which could be related to its antioxidant potential (Table 4). Medium containing polar and non-polar solvents has the capacity to release the cell wall bound polyphenols from the cells and neutralize the activity of poly phenol

TABLE 2: NUTRIENT COMPOSITION OF PULP AND PEEL OF NENDRAN BANANA (FWB)

\begin{tabular}{lcccc}
\hline Parameter & Peel & Pulp & $\begin{array}{c}\text { p } \\
(\mathbf{0 . 0 5 )}\end{array}$ & $\begin{array}{c}\text { t-value } \\
(5 \%)\end{array}$ \\
\hline Moisture (\%) & $75.3 \pm 3.2$ & $62.0 \pm 2.87$ & 1.24 & 2.34 \\
TSS ${ }^{\circ}$ Bx & $6.4 \pm 0.25$ & $21.5 \pm 0.81$ & 0.43 & -24.18 \\
Reducing sugar & $12.6 \pm 0.47$ & $17.8 \pm 0.64$ & 0.57 & -10.23 \\
(\%) & & & & \\
Non-reducing & $3.4 \pm 0.19$ & $5.4 \pm 0.09$ & 0.67 & -11.76 \\
sugar (\%) & $4.5 \pm 0.11$ & $7.6 \pm 0.19$ & 0.28 & -10.21 \\
Starch (\%) & $0.35 \pm 0.004$ & $0.83 \pm 0.04$ & 0.23 & -10.72 \\
Protein (\%) & $3.67 \pm 0.20$ & $2.58 \pm 0.12$ & 0.64 & 09.27 \\
Fat (\%) & $22.6 \pm 1.62$ & $32.5 \pm 1.99$ & 0.42 & -2.85 \\
Total & & & & \\
carbohydrate (\%) & & & &
\end{tabular}

TABLE 3: MINERAL CONTENT OF PULP AND PEEL SAMPLES OF NENDRAN (FWB)

\begin{tabular}{lcccc}
\hline Parameter & Peel & Pulp & $\begin{array}{c}\text { P } \\
(\mathbf{0 . 0 5 )}\end{array}$ & $\begin{array}{c}\text { t-value } \\
(\mathbf{5} \%)\end{array}$ \\
\hline $\begin{array}{l}\text { Potassium } \\
\text { (mg/100 g) }\end{array}$ & $618.4 \pm 25.74$ & $397.9 \pm 15.05$ & 0.43 & 13.11 \\
Calcium (ppm) & $220.0 \pm 08.32$ & $130.0 \pm 04.68$ & 0.57 & 13.76 \\
$\begin{array}{l}\text { Magnesium } \\
\text { (ppm) }\end{array}$ & $536.0 \pm 30.37$ & $421.0 \pm 7.29$ & 0.67 & 4.2 \\
Iron (ppm) & $12.4 \pm 0.32$ & $4.7 \pm 0.11$ & 0.29 & 17.59 \\
Zinc (ppm) & $2.8 \pm 0.06$ & $1.4 \pm 0.06$ & 0.56 & 11.43 \\
Manganese & $2.3 \pm 0.07$ & $1.3 \pm 0.05$ & 0.63 & 18.8 \\
(ppm) & $38.0 \pm 2.91$ & $22.0 \pm 1.34$ & 0.42 & 3.95 \\
\hline Sodium (ppm) & 350 & & &
\end{tabular}

TABLE 4: SECONDARY METABOLITES AND ANTIOXIDANT POTENTIAL OF PULP AND PEEL OF NENDRAN (FWB)

\begin{tabular}{lcccc}
\hline Parameter & Peel & Pulp & $\begin{array}{c}\mathrm{p} \\
(0.05)\end{array}$ & $\begin{array}{c}\mathrm{t}-\mathrm{value} \\
(5 \%)\end{array}$ \\
\hline $\begin{array}{l}\text { Total phenols } \\
(\mathrm{mg} / \mathrm{g})\end{array}$ & $0.54 \pm 0.02$ & $0.82 \pm 0.03$ & 0.42 & -14.39 \\
$\begin{array}{l}\text { Total flavonoids } \\
(\mu \mathrm{g} / \mathrm{g})\end{array}$ & $51.47 \pm 1.94$ & $49.20 \pm 1.77$ & 0.67 & 1.39 \\
$\begin{array}{l}\text { Total carotenoids } \\
(\mu \mathrm{g} / \mathrm{g})\end{array}$ & $14.6 \pm 0.33$ & $15.8 \pm 0.78$ & 0.56 & -1.26 \\
$\begin{array}{l}\text { B carotene }(\mu \mathrm{g} / \mathrm{g}) \\
\text { Ascorbate }\end{array}$ & $10.3 \pm 0.33$ & $12.6 \pm 0.59$ & 0.63 & -4.62 \\
$\begin{array}{l}\text { peroxidase } \\
(\mu \mathrm{mol} / \mathrm{mg} / \mathrm{min})\end{array}$ & $8.7 \pm 0.66$ & $18.9 \pm 1.15$ & 0.42 & -5.91 \\
$\begin{array}{l}\text { Catalase }(\mu \mathrm{mol} / \\
\mathrm{mg} / \mathrm{min})\end{array}$ & $6.98 \pm 0.41$ & $9.35 \pm 0.47$ & 0.26 & -2.77 \\
$\begin{array}{l}\text { Peroxidase } \\
(\mu \mathrm{mol} / \mathrm{mg} / \mathrm{min})\end{array}$ & $30.74 \pm 1.27$ & $10.74 \pm 0.41$ & 0.42 & 2.11 \\
SOD $(\mathrm{U} / \mathrm{mg} / \mathrm{min})$ & $1.36 \pm 0.05$ & $2.97 \pm 0.11$ & 0.57 & -18.92 \\
\hline $\begin{array}{l}\mathrm{n}=8) \\
\end{array}$ & & & &
\end{tabular}


oxidase, which generally degrades the polyphenols in plants ${ }^{[21]}$. Phenols and flavonoids, the bioactive health beneficial phytochemicals, implicated in the prevention of a variety of diseases like cardiovascular diseases, cancers and neurodegenerative disorders was documented by researchers in different plant parts ${ }^{[24-29]}$.

FRAP assay (fig. 1a) is a widely used method that uses antioxidants as reductants in a redox-linked colorimetric reaction. The ferric reducing capability was found better with peel than the pulp. With the concentration of $300 \mu \mathrm{g} / \mathrm{ml}$, the peel has the antioxidant activity, matched with the BHA standard. Phenols and carotenoids were responsible for the higher FRAP activity in the peel. Carotenoids have good effect on human health, such as pro-vitamin A, antioxidant, anticancer, antiobesity effect and anabolic effect on bone components, which accumulated highly in pulp than pee ${ }^{[20]}$. The higher carotenoid content of Nendran, make it as a nutraceutical variety and gives its intense yellow colour while ripening ${ }^{[19]}$.

The ability of the methanol extract of the Nendran peel to scavenge free radicals was determined based on its hydrogen donating ability in the DPPH assay (fig. 1b). The free radical scavenging activity of the extract was expressed as an $\mathrm{IC}_{50}$ of $180.33 \mu \mathrm{g} / \mathrm{ml}$, which could be due to the presence of high flavonoid content, which might play a key role with its proton donating ability and could serve as free radical scavengers, acting possibly as primary antioxidants ${ }^{[13]}$. Previous studies reported the antioxidant potential of extracts of banana pulp and peel with varying $\mathrm{IC}_{50}$ values ${ }^{[13,29]}$. Similar to FRAP, in the present study, the DPPH free radical scavenging activity of the peel reached its peak at a concentration of $300 \mu \mathrm{g} / \mathrm{ml}$ of extract and remained

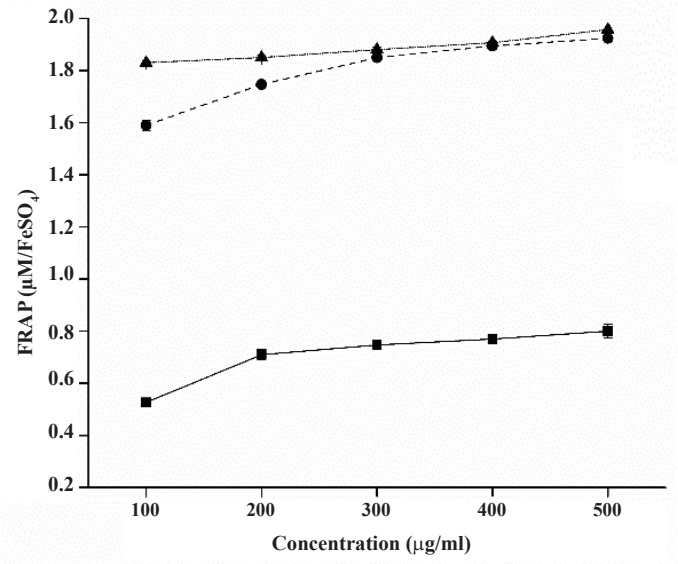

Fig. 1: Concentration-response of Nendran peel extract in FRAP and DPPH assays a. Concentration-response of Nendran extracts in FRAP assay $\left(\mu \mathrm{M} / \mathrm{FeSO}_{4}\right)$ and $(\mathrm{b})$ in DPPH assay (\% inhibition) $\mathrm{IC}_{50}$ values of pulp

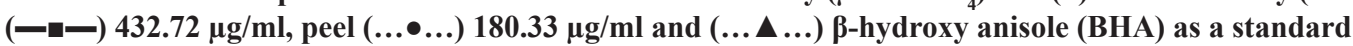



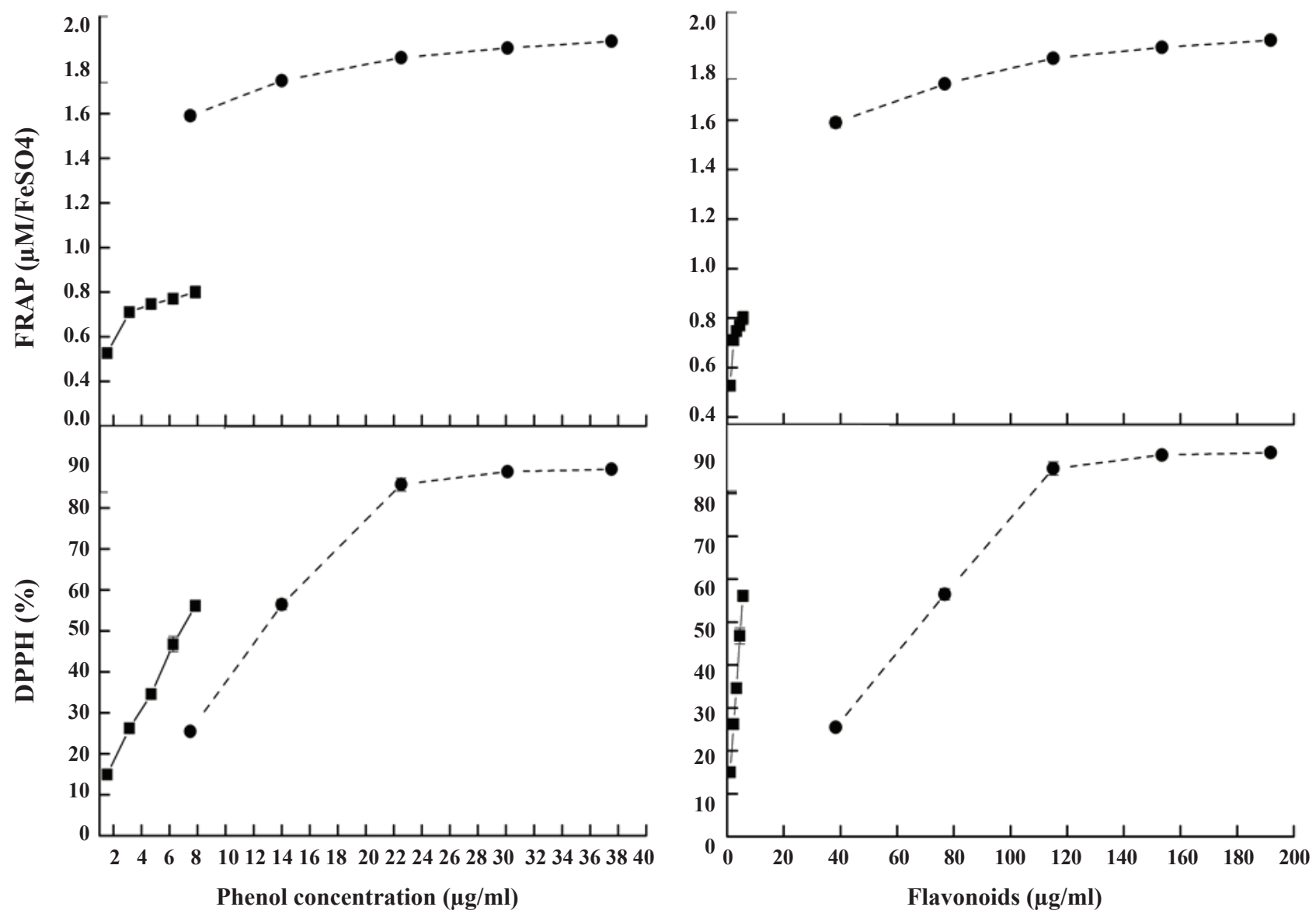

Fig. 2: Correlation between phenol and flavonoid content and antioxidant activity of Nendran banana Correlation between total phenol and flavonoid content of pulp (- - and peel (...•...) of Nendran and antioxidant activity

activity. FRAP activity showed significantly positive correlation with total phenols and carotenoids whereas the DPPH activity was higher with the flavonoid content. This explained the fact that more antioxidant activity is required to study the full potential of extracts of natural products. Depending upon the results, further isolation and characterization could be decided.

The anticancer properties of the pulp with its tumour necrosis factor were already reported by various researchers ${ }^{[11,19,23]}$. With higher content of phenols and flavonoids, the peel of Nendran bananas was chosen for evaluation of anticancer potential on MCF-7 cells. MCF-7 cell line has become a prominent model system for breast cancer studies as it relates to the susceptibility of the cells to apoptosis. Even though many tumours initially respond to chemotherapy, breast cancer cells can subsequently survive and develop resistance to the treatment. The inhibitory effect on breast cancer cells at different concentrations of peel extract of Nendran banana was studied. The dose-response relationship of the extract shown in Table 5. The intensity of darkblue colour developed by the MTT reaction is directly proportional to the number of viable cancer cells. Cell
TABLE 5: EFFECT OF NENDRAN PEEL EXTRACT ON CELL VIABILITY AND CYTOTOXICITY OF MCF7 CELL LINE

\begin{tabular}{lcc}
\hline $\begin{array}{l}\text { Extract concentration } \\
(\mu \mathrm{g} / \mathrm{ml})\end{array}$ & Cell viability (\%)* & $\begin{array}{c}\text { Cytotoxicity } \\
(\%)\end{array}$ \\
\hline Control & $100 \pm 0.00(90.00)$ & 0 \\
200 & $24.7 \pm 1.10(29.76)$ & 75.3 \\
180 & $48.08 \pm 0.86(43.88)$ & 51.92 \\
160 & $55.02 \pm 1.24(47.86)$ & 44.98 \\
140 & $56.78 \pm 0.64(48.87)$ & 43.22 \\
120 & $59.73 \pm 1.48(50.60)$ & 40.27 \\
100 & $67.58 \pm 0.58(55.29)$ & 32.42 \\
80 & $70.72 \pm 0.45(57.22)$ & 29.28 \\
60 & $74.26 \pm 0.97(59.50)$ & 25.74 \\
40 & $80.52 \pm 0.96(63.81)$ & 19.48 \\
20 & $91.14 \pm 2.34(72.94)$ & 8.86 \\
\hline
\end{tabular}

*value in parenthesis are actual numbers recorded during the experiment $(n=8)$

viability (\%) indicates the number of living cells. As the concentration of sample increased $(\mu \mathrm{g} / \mathrm{ml})$, the absorbance decreased that related to cell viability (\%). As the concentration increased from 20 to $200 \mu \mathrm{g} / \mathrm{ml}$, the cell viability of MCF-7 decreased from 91.14 to $24.7 \%$. Cytotoxicity of the sample extract with varying concentration was also studied (Table 6). We noticed 
TABLE 6: IC $_{50}$ VALUES AND REGRESSION COEFFICIENT OF CELL VIABILITY TEST WITH NENDRAN PEEL IN MTT ASSAY

\begin{tabular}{lc}
\hline $\begin{array}{l}\text { Log(inhibitor) vs. normalized } \\
\text { response -- Variable slope }\end{array}$ \\
\hline \multicolumn{2}{l}{ Best-fit values } \\
\hline Log IC & \\
Hill Slope & 2.081 \\
IC50 & -2.113 \\
LogIC & 120.6 \\
Hill Slope & 0.02057 \\
$95 \%$ Confidence intervals & 0.2733 \\
Log IC & \\
Hill Slope & 2.039 to 2.123 \\
$I_{50}$ & -2.673 to -1.554 \\
R square & 109.4 to 132.9 \\
\hline
\end{tabular}

that in control, mortality was not found on the cell population whereas with the concentration of $100 \mu \mathrm{g} / \mathrm{ml}$, cytotoxicity of sample found to be $32.42 \%$ while with $200 \mu \mathrm{g} / \mathrm{ml}$ of sample showed the mortality of $75.3 \%$ of cancer cells, which implied the effectiveness of peel extract against the cancer. The half maximal inhibitory concentration $\left(\mathrm{IC}_{50}\right)$ is a measure of the effectiveness of a substance in inhibiting a specific biological or biochemical function. This quantitative measure indicates how much of inhibitor (sample) is required to inhibit a given biological process. In our present study, the extract of Nendran peel recorded $\mathrm{IC}_{50}$ of $120.6 \mu \mathrm{g} / \mathrm{ml}$. Therefore, it can be concluded that the effective concentration of the sample to arrest the cancer cell was $120.6 \mu \mathrm{g} / \mathrm{ml}$, which recorded the regression coefficient value of 0.85 . This explained the best fit of the model system followed for the experiment.

These changes were more visible in the dose response curve (fig. 3) plotted with OD value versus increasing concentration of the sample. The intensity of colour decreased with higher concentration of the extract with the values falling from $0.45 \mathrm{OD}$ value at $570 \mathrm{~nm}$ in control to $0.05 \mathrm{OD}$ value with the concentration of $200 \mu \mathrm{g} / \mathrm{ml}$. The effect of peel extract on change in the cell viability was examined under the microscope (fig. 4) and the formazan crystals formed in the viable cell was noticed. The number of viable cells was more in untreated MCF-7 cells than in the Nendran peeltreated samples. This indicated the potential of peel as an anticancer agent and the presence of bio-active compounds, which had the capability to suppress the cell proliferation.

Tumor cells undergo apoptosis in the presence of anticancer drugs while normal cells become necrotic if the drug is toxic. MTT assays cannot differentiate between these mechanisms of cell death. Therefore, the effects of drug may primarily be toxic or poisoning to normal cells. These drugs have limited clinical application ${ }^{[11,31,32]}$. Therefore, detection of tumor cell apoptosis is more valuable than generally assessing tumour cell viability. To distinguish normal, early apoptotic, late apoptotic cells, and dead cells, nuclear morphology must be assessed. Fluorescent staining using $\mathrm{AO}$ alone has been used in the past; however, detection of cell apoptosis using $\mathrm{AO} / \mathrm{EB}$ is a relatively new approach, and few papers have reported its use $^{[33-39]}$. Dual AO/EB fluorescent staining can detect basic morphological changes in apoptotic cells. In addition, it allows for the distinction between normal cells, early and late apoptotic cells, and necrotic cells. Therefore, $\mathrm{AO} / \mathrm{EB}$ staining is a qualitative and quantitative method to detect apoptosis ${ }^{[18]}$.

Plant extract treated $\mathrm{MCF}-7$ cells were subjected to $\mathrm{AO} / \mathrm{EB}$ staining. $\mathrm{AO}$ will enter the nucleus and stain live cells as green colour fluorescence and EB will penetrate the nucleus of dead cells due to loss of membrane integrity and stain as red colour fluorescence (fig. $5 \mathrm{a}$ and $5 \mathrm{~b}$ ) when bound to concentrated DNA fragments or apoptotic bodies ${ }^{[18,40]}$. In the present study, the MCF-7 cells were treated with $120.6 \mu \mathrm{g} / \mathrm{ml}$ of plant extract and the cells were examined using fluorescent microscopy. Normal viable cells appeared as green fluorescence with highly organized nuclei. Early apoptotic cells (28\%) were appeared as a crescentshaped or granular yellow-green with $\mathrm{AO}$ nuclear staining. Late apoptotic cells (65\%) were appeared as a concentrated and asymmetrically localized orange nuclear ETBr staining ${ }^{[33-36]}$ (fig 6). Necrotic cells (7\%) showed uneven, orange-red fluorescence at their periphery without chromatin fragmentation. The $\mathrm{IC}_{50}$ values of plant extracts-treated cells $(120.6 \mu \mathrm{g} / \mathrm{ml})$ showed typical apoptotic and necrotic morphological features such as condensed nuclei, membrane blebbing

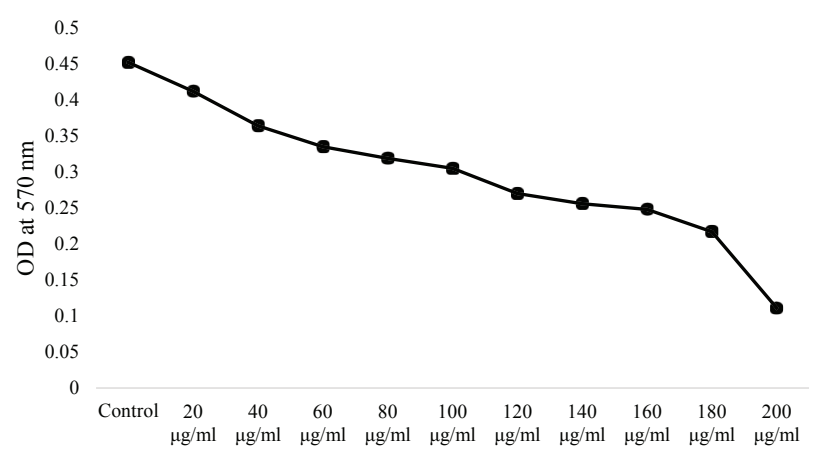

Fig. 3: Dose response of Nendran peel extract on MCF-7 cells Dose response curve of different concentrations $(\mu \mathrm{g} / \mathrm{ml})$ of Nendran peel extract on MCF-7 cells 


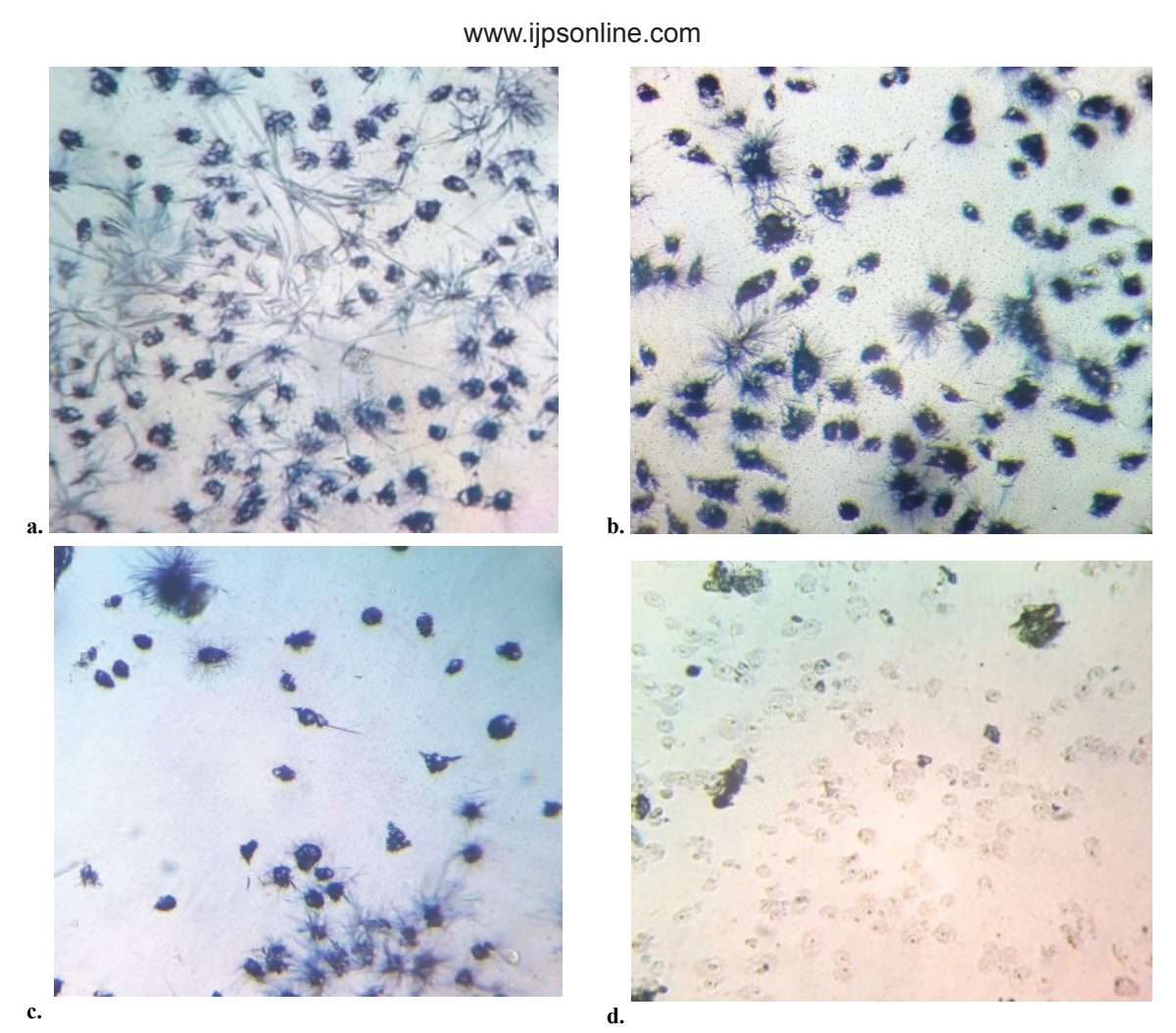

Fig. 4: Effect of Nendran peel extract on the presence of viable cells through formation of formazan crystals after MTT treatment Influence of varying concentrations of Nendran peel extract on the presence of viable cells through formation of formazan crystals after MTT treatment (a) control, (b) cell behaviour at $40 \mu \mathrm{g} / \mathrm{ml}$, (c) cell behaviour at $100 \mu \mathrm{g} / \mathrm{ml}$ and (d) cell behaviour at $200 \mu \mathrm{g} / \mathrm{ml}$
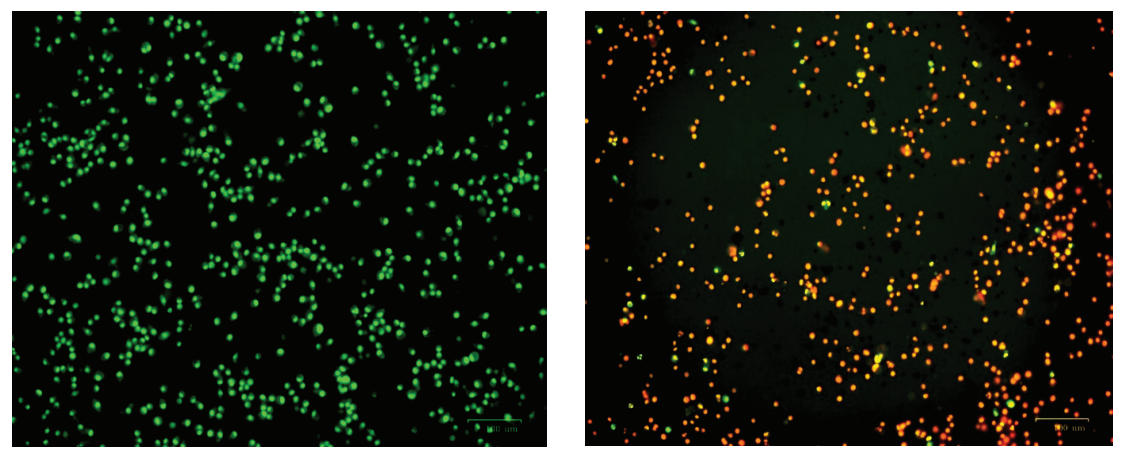

a.

b.

Fig. 5: AO/EB staining of MCF-7 cell line treated with peel extract of Nendran banana

Acridine orange/ethidium bromide (AO/EB) staining of MCF-7 cell lines (a) before treatment and (b) after treatment with peel extract of Nendran banana

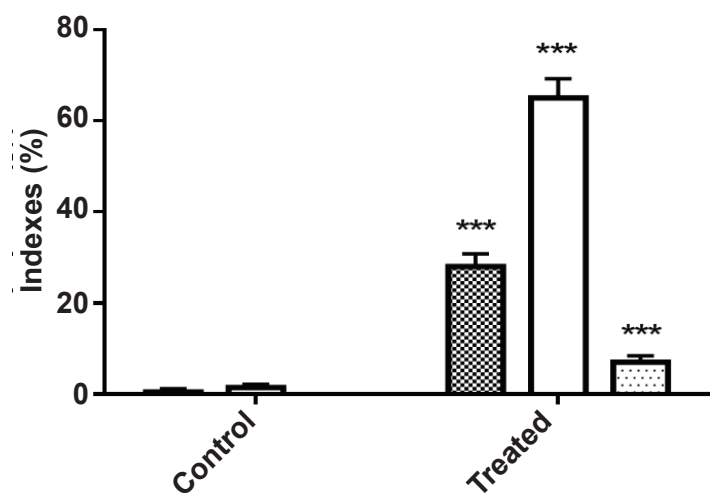

Fig. 6: Effect of peel extract on early, late apoptosis and necrosis of MCF-7 cells

(빠) Early apoptosis, ( $\square$ ) late apoptosis, $(\sqsupset)$ necrosis (\%) and formation of apoptotic bodies, which were clearly observed under the fluorescence microscope ${ }^{[24,12]}$. These changes imply the cells appeared to be in the process of disintegrating. Whereas in control, the nucleus of the cells was regular in shape with no changes and retained the green colour. Our experiment result on anticancer activity of banana peel extract was corroborated with the earlier reports showing the similar efficacy with different parts like pulp ${ }^{[11,39,40]}$ and seed ${ }^{[7,9,11]}$ in inhibition of cancer cell lines.

The present investigation provides the gateway of information that aqueous methanol extract of Nendran peel has potent cytotoxic activity against MCF-7 breast 
cell lines. Analysis of the extract showed the presence of high flavonoid content, a secondary metabolite, which is responsible for various therapeutic effects. The result obtained in this study clearly demonstrates that banana fruit peel has a broad spectrum of biological activities and could be used as a good source of antioxidant and antitumour agent. However, further research is needed to identify the bio-active components in banana peel extracts, their purification and characterization of compounds coupled with the evaluation of their mode of action to use the peel extracts in pharmaceutical industries.

\section{Acknowledgments:}

The authors thank the Director, ICAR-NRCB, Trichy for providing infrastructure facilities to carry out the research work. The authors also thank DBT for providing fund to carry out the work under North Eastern project. The Trichy research centre for Biotechnology Laboratory is also acknowledged for doing the antitumor assay. The technical help rendered by Dr. J. Jeyabaskaran and Mr. R. Pitchaimuthu is also acknowledged.

\section{REFERENCES}

1. Mukherjee AK, Basu S, Sarkar N, Ghosh AC. Advances in cancer therapy with plant based natural products. Curr Med Chem 2001;8:1467-86.

2. Lazarus D. Radiolarians decreased silicification as an evolutionary response to reduced Cenozoic ocean silica availability. Proc Nat Acad Sci USA 2009;106:9333-8.

3. Mani RK, Kavitha K, Singh JD, Thakore P. A brief review of plants having anticancer property. Int J Pharm Res 2010;48:64-8.

4. Shixin D, Brett J, West C, Jarakae J. A quantitative comparison of phytochemical components in global noni fruits and their commercial products. Food Chem 2010;31:935-8.

5. Unnati S, Ripal S, Sanjeev A, Niyati A. Novel anticancer agents from plant sources. Chin J Nat Med 2013;11:16-23.

6. Demain AL, Vaishnav P. Natural products for cancer chemotherapy. Microb Biotechnol 2011;4:687-99.

7. Liu RH. Potential synergy of phytochemicals in cancer prevention: mechanism of action. J Nutr 2004;134:3479-85.

8. Kumar PS, Singh Y, Nangare DD, Bhagat K, Kumar M, Taware $\mathrm{PB}$, et al. Influence of growth stage specific water stress on the yield, physic-chemical quality and functional characteristics of tomato grown in shallow basaltic soils. Sci Hortic 2015:197C;261-71.

9. Prasad KN, Hao J, Shi J, Liu T, Li J, Wei X. Antioxidant and anticancer activities of high pressure-assisted extract of longan (Dimocarpus longan Lour.) fruit pericarp. Innov Food Sci Emerg 2009;10:413-9.

10. Praveena M, Prabha MS, Ravi I, Vaganan MM. Anti-colorectal cancer properties of Hill banana (cv. Virupakshi AAB) fruits: An in vitro assay. Indian J Nat Sci 2018:8(47);13226-33.

11. Suresh Kumar P, Shiva KN, Mayil Vaganan M, Uma S. Waste utilization and functional foods from Banana. Indian Hortic 2018;63(4):43-6.

12. Zhang CR, Jayasree E, Suresh Kumar P, Nair MG. Antioxidant and Anti inflammatory compounds in nutmeg (Myristica fragrans) pericarp as determined by in vitro assays. Nat Prod Commun 2015;10(8):1399-402.

13. Rahmat A, Rosli R, Zain WN, Endrini S, Sani HA. Antiproliferative activity of pure lycopene compared to both extracted lycopenes and juices from watermelon (Citrullus vulgaris) and papaya (Carica papaya) on human breast and liver cancer cell lines. J Med Sci 2002;5:2097-103.

14. Chen KC, Peng CC, Chiu WT, Cheng YT, Huang GT, Hsieh CL. Action mechanism and signal pathways of Psidium guajava L. aqueous extract in killing prostate cancer LNCaP cells. Nutr Cancer 2010;62:260-70.

15. Miller EG, Porter JL, Binnie WH, Guo IY, Hasegawa S. Further studies on the anticancer activity of citrus limonoids. J Agric Food Chem 2004;60:69-74.

16. Arora M, Kaur P. Antimicrobial \& antioxidant activity of orange pulp and peel. Int J Sci Res 2013;2:412-5.

17. Manosroi J, Dhumtanom P, Manosroi A. Anti-proliferative activity of essential oil extracted from Thai medicinal plants on KB and P388 cell lines. Cancer Lett 2006;235:114-20.

18. Tsamo CVP, Herent M, Tomekpe K, Emaga TH, QuetinLeclercq J, Rogez H, et al. Phenolic profiling in the pulp and peel of nine plantain cultivars (Musa sp.). Food Chem 2015;15:197-204.

19. Orhue PO, Momoh AR. Antibacterial activities of different solvent extracts of Carica papaya fruit parts on some gram positive and gram-negative organisms. Int J Herbs Pharmacol Res 2013;2:42-7.

20. Kumar KPS, Bhowmik D, Duraivel S, Umadevi M. Traditional and medicinal uses of banana. J Pharmacogn Phytochem 2012;1:51-63.

21. Emaga TH, Andrianaivo RH, Wathelet B, Paquot M. Effects of the stage of maturation and varieties on the chemical composition of banana and plantain peels. Food Chem 2007; 103:590-600.

22. Ighodaro O. Evaluation study on Nigerian species of Musa paradisiaca peels: phytochemical screening, proximate analysis, mineral composition and antimicrobial activities. Researcher 2012;4:17-20.

23. Li ZY, Wang Y, Shen WT, Zhou P. Content determination of benzyl glucosinolate and anti-cancer activity of its hydrolysis product in Carica papaya L. Asian Pac J Trop Med 2012;72:382-5.

24. Ciniglia C, Pinto G, Sansone C, Pollio A. Acridine orange/ Ethidium bromide double staining test: A simple In-vitro assay to detect apoptosis induced by phenolic compounds in plant cells. Allelopathy J 2010;26(2):301-8.

25. Benzie IFF, Strain JJ. The ferric reducing ability of plasma (FRAP) as a measure of "antioxidant power": The FRAP assay. Anal Biochem 1996;239;70-6.

26. Houston MC. Treatment of Hypertension with Nutrachemicals, Vitamins, Antioxidants and Minerals. Expert Rev Cardiovasc Ther 2007;5:681-91.

27. Karppanen H. Minerals and Blood pressure. Ann Med 1991;23:299-305.

28. Donovan JL, Meyer AS, Waterhouse AL. Phenolic composition and antioxidant activity of prunes and prune juice (Prunus domestica). J Agric Food Chem 1998;46:1247-52. 
29. Ediriweera ER, Rathnasooriya WD. A review of herbs used in diabetes mellitus by Sri Lankan Ayurvedic and traditional physicians. Ayu 2009;30:373-91.

30. Freitas D, Glories Y. Concentration and compositional changes of procyanidins in grape seeds and skin of white Vitis vinifera varieties. J Sci Food Agric 1999;79:1601-6.

31. Ghasemi K, Ghasemi Y, Ebrahimzadeh MA. Antioxidant activity, phenol and flavonoid contents of 13 citrus species peels and tissues. Pak J Pharm Sci 2009;22:277-81.

32. González-Gallego J, García-Mediavilla MV, Sánchez-Campos S, Tuñón MJ. Fruit polyphenols, immunity and inflammation. Br J Nutr 2010;104:15-27.

33. Goulas V, Manganaris G. Exploring the phytochemical content and the antioxidant potential of Citrus fruits grown in Cyprus. Food Chem 2012;131:39-47.

34. Huang ME. Oxygen metabolism and reactive oxygen species cause chromosomal rearrangements and cell death. Microb Biotechnol 2009;104:9747-52.
35. KimH, Moon JY, Kim H, Lee DS, Cho M, Choi HK. Antioxidant and antiproliferative activities of mango (Magnifera indica L.) flesh and peel. Food Chem 2010;121:429-36.

36. Maria GA, Sonia PT, Celestino SB, Julian CRG. Evaluation of the antioxidant properties of fruits. Food Chem 2004;50:88992.

37. Lecoeur H. Nuclear apoptosis detection by flow cytometry: influence of endogenous endonucleases. Exp Cell Res 2002;277:1-14.

38. Burda S, Oleszek W, Lee CY. Phenolic compounds and their changes in apples during maturation and cold storage. J Agric Food Chem 1990;38:945-8.

39. Senthilraja P, Kathiresan K. In vitro cytotoxicity MTT assay in Vero, HepG2 and MCF -7 cell lines study of Marine Yeast. J Appl Pharm Sci 2015;55:689-94.

40. Sumathy N, Sumathy J. Antibacterial and antifungal activity of musa fruit peels against skin and gastrointestinal tract diseases. Herbal Tech Ind 2011;4:11977-83. 